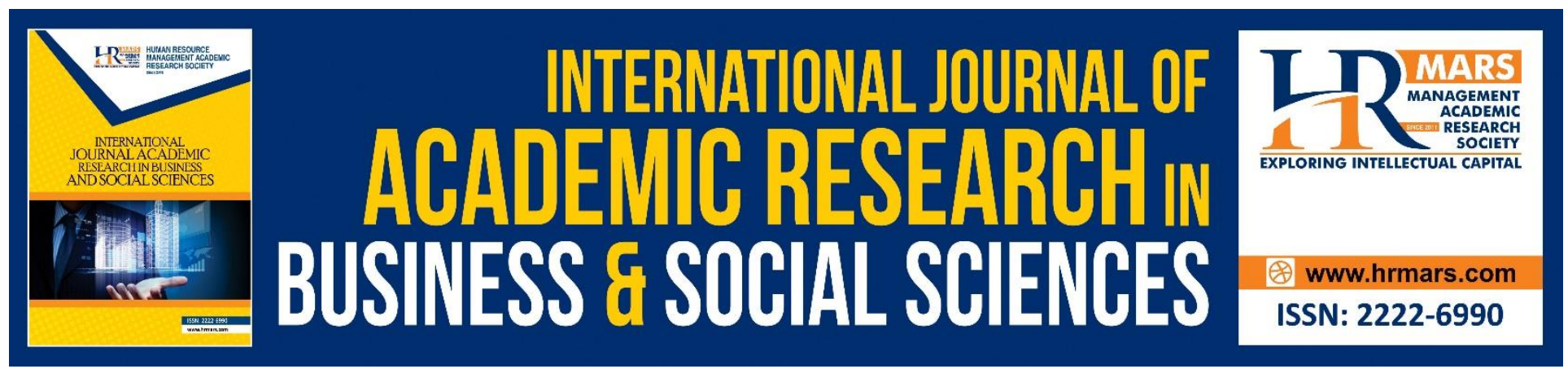

\title{
Malaysian Public's Concern About the Environment During the Covid-19 Pandemic: A Study of a Selected State in Peninsular Malaysia
}

Dzuhailmi Dahalan, Haliza Abdul Rahman and Jeffrey Lawrence D'Silva

To Link this Article: http://dx.doi.org/10.6007/IJARBSS/v10-i15/8423

DOI:10.6007/IJARBSS/v10-i15/8423

Received: 01 November 2019, Revised: 29 November 2020, Accepted: 15 December 2020

Published Online: 30 December 2020

In-Text Citation: (Dahalan et al., 2020)

To Cite this Article: Dahalan, D., Rahman, H. A., \& D'Silva, J. L. (2020). Malaysian Public's Concern About the Environment During the Covid-19 Pandemic: A Study of a Selected State in Peninsular Malaysia.

International Journal of Academic Research in Business and Social Sciences, 10(15), 368-378.

Copyright: (C) 2020 The Author(s)

Published by Human Resource Management Academic Research Society (www.hrmars.com)

This article is published under the Creative Commons Attribution (CC BY 4.0) license. Anyone may reproduce, distribute, translate and create derivative works of this article (for both commercial and non-commercial purposes), subject to full attribution to the original publication and authors. The full terms of this license may be seen

at: http://creativecommons.org/licences/by/4.0/legalcode

Special Issue: Youth and Community Wellbeing: Issues, Challenges and Opportunities for Empowerment V1, 2020, Pg. 368 - 378 http://hrmars.com/index.php/pages/detail/IJARBSS JOURNAL HOMEPAGE

Full Terms \& Conditions of access and use can be found at http://hrmars.com/index.php/pages/detail/publication-ethics 


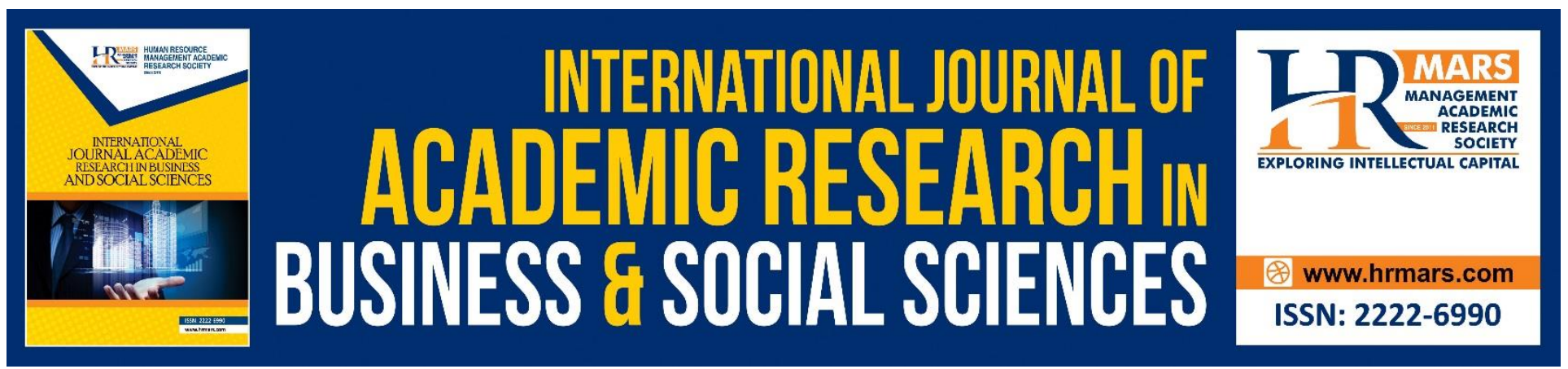

\section{Malaysian Public's Concern About the Environment During the Covid-19 Pandemic: A Study of a Selected State in Peninsular Malaysia}

\section{${ }^{1}$ Dzuhailmi Dahalan, ${ }^{1,2}$ Haliza Abdul Rahman and ${ }^{1}$ Jeffrey Lawrence D'Silva}

${ }^{1}$ Institute for Social Science Studies, Putra Infoport, Universiti Putra Malaysia, 43400, UPM Serdang, Selangor, Malaysia, ${ }^{2}$ Faculty of Medicine and Health Sciences, Universiti Putra Malaysia, 43400, UPM Serdang, Selangor, Malaysia

Email: dzuhailmi@upm.edu.my

\section{Abstract}

This article examines the level of concern of the Malaysian community towards the environment in a selected state of Peninsular Malaysia during the Covid-19 pandemic. The findings of the study presented are based on a quantitative study involving a total of 211 respondents. This is part of the findings of a real study involving the Malaysian society in general across the state. Overall, this case study found that the respondents' level of concern for the environment during the Covid-19 pandemic was at a high level. However, the level of green consumption practices in society was still seen at a moderate level. There was no significant difference in terms of their level of concern for the environment during the Covid-19 pandemic either among respondents living in urban or rural areas. Similar findings were shown for single and married respondents. In short, the findings of the study show a very positive sign among some parts of Malaysian society towards realising the efforts to preserve the environment by various parties in Malaysia. Therefore, this study argues that the efforts to educate the community that have been done by various parties should be seen as a profitable investment. In fact, it is necessary to secure continuous support from various parties in the community towards the preservation of a sustainable environment, especially in terms of increasing the level of green consumption practices among the community.

Keywords: Concern, environmental sustainability, Covid-19 Pandemic, Movement Control Order, Malaysian Society

\section{Introduction}

The 50th anniversary of Earth Day celebration celebrated on April 22, 2020 was commemorated and celebrated when the Covid-19 pandemic hit almost 210 countries and territories around the world. In Malaysia, the Minister of Environment and Water, YB Dato' Tuan Ibrahim Tuan 
Man in his Earth Day special speech reported that the level of Air Pollution Index (IPU) dropped 14\% to record a "clean index" while $28 \%$ of the 29 automatic water monitoring station readings showed an increase in water quality during the enforcement of the Movement Control Order (MCO) (Meenakshi, 2020).

This good API reading is said to be due to the decrease in environmental pollution activities as a result of the MCO enforcement. Among the activities are gas emissions from motor vehicles, industrial air funnels and open combustion. If the enforcement of the MCO, which restricts the movement of society in Malaysia, is said to have a positive impact on environmental sustainability, then what has happened can be described as something unintentional. The concerns are: will some Malaysians revert to greedly tarnish the sanctity of the environment after the enforcement of the MCO? Does the enforcement of MCO fail to enlighten us on the aesthetic value of the environment which should rightfully be preserved?

Humans and the environment are indeed closely related. Humans affect the environment and vice versa. The environment is an element of the human environment both in the forms of biotic and abiotic components. However, humans, as the dominant species, are more pronounced in transforming the natural state of the environment into various other physical forms through various development activities. In Malaysia, there is no denying that the implementation of socio-economic development projects has been so significant in the past, which to some extent has a negative impact on the environment. Although this vibrant development may be said to be under control, it will still be associated with environmental issues. Among them are global warming, the drastic decline in natural resource reserves, the depletion of the ozone layer, the extinction of biodiversity and other issues that demand the efficiency of environmental management by all parties (Ahmad et. al., 2011). Since environmental issues stem from human actions, all parties need to think about the need to produce a generation of society that is not only concerned but also is actively responsible for the environment.

Thus, sustainable development has been proposed for the continuity of human life and the well-being of the global environment. This shows that humans have little choice; they need to show concern as well as to transform in terms of practices and attitudes in their daily interactions with the environment to a more positive form so that both entities could obtain benefits accordingly. Indeed, this is crucial because a high level of environmental awareness is an important element towards sustainable development (Zurina \& Norjan 2003).

Realising the fact that human beings are important characters in the aspect of environmental sustainability, their concern over this issue should not be 'seasonal'. In other words, the physical and social pressures that pressed people during the enforcement of the MCO due to the Covid-19 pandemic should not be used as a reason for the society to be indifferent to the environment and as if not a single useful lesson is gleaned from the MCO scenario that has 'gifted something' to the environment. In this regard, this paper examines the level of public concern in one of the selected states of Peninsular Malaysia towards the environment during the Covid-19 pandemic. Wahid et. al. (2011) stated that such a study is very important towards maintaining 
INTERNATIONAL JOURNAL OF ACADEMIC RESEARCH IN BUSINESS AND SOCIAL SCIENCES

Vol. 10, No. 15, Youth and Community Wellbeing: Issues, Challenges and Opportunities for Empowerment V1. 2020, E-ISSN: $2222-6990$ ๑ 2020 HRMARS

environmentally friendly practices and conservation behavior for the well-being of future generations.

\section{Literature Review}

Malaysia faces serious challenges towards achieving sustainable development in the future (Said et. al., 2003). This observation is based on the environmental issues such as air and river water quality, deforestation and hazardous waste disposal, among others, which are still plaguing the country. All of these issues are said to stem from the unsatisfactory level of awareness among the community towards the environment (Idrus, 2015). There is a conclusion that the society only cares about the affairs of their daily life but not on environmental issues (Ashaario, 2009).

Previous studies indicate that environmental awareness among Malaysians is still worryingly low, compared to developed countries such as Japan, Denmark and Germany (Malaysia Environmental Department, 1997). Mutalib (2019) believes that the concern to protect the environment and the surrounding areas among Malaysians is still at a low level. Although various policies and awareness campaigns have been implemented by the government, the private sector and Non-Governmental Organizations (NGOs) to cultivate this awareness, it seems as if those efforts have yet to bring the expected results.

Previous studies also indicate that many members of the public still think that the government should be the party to actively play a role in protecting the environment. The study of Zurina and Norjan (2003) found that society is more focused on environmental issues that are close to them, but their level of awareness is minimal, especially in terms of their involvement in overcoming those enviromental issues. According to Wahid et. al., (2011), the level of accountability among consumers in Malaysia towards the environment is still low, especially in terms of behavior. The study of Samsudin \& Iksan (2015) also found similar findings. In other words, their concern for environmental issues is still minimal. Not many express their awareness in the form of practice (Starke, 1990). This also means that most people are concerned about the environment, but their responses reflect otherwise.

In the context of the State of Selangor, the study of Sabri and Yong (2006) showed that more than $70 \%$ of the respondents surveyed have a high level of concern for the environment but have a moderate level of green consumption practices, in which most respondents only sometimes use green products. It is also found that newspapers and television are their main sources of information and that they have a positive perception of green products. A detailed analysis of their study found that there was a positive and significant correlation between the level of environmental concern and green consumption practices $(r=0.301, p:<0.01)$.

In other words, the higher the level of concern for the environment, the higher the level of green consumerism among consumers. Their study, which aims to examine the level of environmental concern and consumer green consumption practices in Petaling Jaya, Selangor, however, only involved a total of 80 employees from a private company operating in the state through systematic sampling methods. Their study also supports the finding of the reseach conducted 
INTERNATIONAL JOURNAL OF ACADEMIC RESEARCH IN BUSINESS AND SOCIAL SCIENCES

Vol. 10, No. 15, Youth and Community Wellbeing: Issues, Challenges and Opportunities for Empowerment V1. 2020, E-ISSN: 2222-6990 @ 2020 HRMARS

by Othman \& Umar (2000) in Petaling Jaya and Kuala Lumpur. The finding indicates that there is an increase in the level of concern among the community on environmental issues, especially among urban consumers in Malaysia.

Concern for the environment can be defined as the sensitivity of the community towards the pertinent environmental issues which is then translated through appropriate attitudes and practices. The word 'Concern' refers to one's interest and in depth attention to something, matter or issue (Fourth Edition Hall Dictionary, 2017). In this context, the something, matter or issue is referring to the environment. Thus, environmental concern is an internal awareness of society about the environmental relations in their lives. This concern will motivate them to strive to improve appropriate knowledge as well as to contribute to the environment (Samsudin \& Iksan, 2015).

The fact remains that neglectful attitudes among the society towards the environment have an unhealthy impact not only on the environment but also the well-being of the society (Ahmad et. al., 2011). In the Qur'an, there is a specific verse regarding the damages that have occured on earth as a result of humans' actions, as Allah SWT says in verse 41 in Surah Ar-Rum, "Corruption has appeared in the land and the sea on account of what the hands of men have wrought, that He may make them taste a part of that which they have done, so that they may return". In short, the society's concern in conserving the environment is seen as the foundation in shaping their attitudes, perceptions, interpretations and behaviors towards the environment.

\section{Methodology}

This cross-sectional study involves Malaysians aged 18 years and above. This quantitative research utilised online questionnaire form, namely Google form application, as a data collection tool, and it was carried out during Phase Two and Three of the MCO. The findings presented descriptively were part of a larger study findings on the interaction of Malaysian society with the environment during the MCO with an estimated total population for the actual study was in the range of 20 million people. Based on the confidence level of $95 \%$ and the margin error of $5 \%$, the sample size should be possible at a total of about 384 respondents. Thus, the actual findings of the number of respondents involved in the larger study is 507 people. However, this article only involves the data in Selangor with a total of 211 respondents. A specific measurement item presented in this article, namely 'Malaysian Community Concerns about the Environment during the Covid-19 Pandemic', were constructed based on selected literatures. Data were analyzed using descriptive and inferential statistics. Mean scores and standard deviations were used to measure the level of respondents' concern for the environment around them when MCO was enforced. Whereas t-independent tests were used to see if there was a significant difference in their level of concern for the environment based on selected demographic variables.

\section{Research Findings and Discussion Respondents' Profile}

Table 1 summarises the distribution of selected demographic profiles of respondents. This study involved $38.4 \%$ male respondents and $61.6 \%$ female respondents. The age profile showed that the majority of respondents (51.7\%) were between $31-40$ years old. This was followed by 
respondents aged $41-50$ years (30.8\%), $51-60$ years ( $8.1 \%), 21-30$ years $(5.7 \%)$ and 61 years and above (3.2\%). Less than $1 \%$ of the respondents involved were aged 20 years and below. The marital status of the respondents showed that $69.7 \%$ of the respondents were married, the rest $(30.3 \%)$ were still single. The majority of them (61.1\%) lived in cities while another $38.9 \%$ lived in rural areas. The average monthly income of respondents showed that the majority of them (36.5\%) had an average monthly income of between RM2,501-RM5,000. This was followed by $23.2 \%$ (RM7,501-RM10,000), 15.6\% (over RM10,000), 15.2\% (RM5,001-RM7,500) and 9.5\% (less than RM2,500).

Table 1: Respondents' Demographic Profile $(n=211)$

\begin{tabular}{|c|c|}
\hline Background & Percentage \\
\hline \multicolumn{2}{|l|}{ Gender } \\
\hline Male & 38.4 \\
\hline Female & 61.6 \\
\hline \multicolumn{2}{|l|}{ Age } \\
\hline$\leq 20$ & 0.5 \\
\hline$\overline{2} 1-30$ & 5.7 \\
\hline $31-40$ & 51.7 \\
\hline $41-50$ & 30.8 \\
\hline $51-60$ & 8.1 \\
\hline $61 \geq$ & 3.2 \\
\hline \multicolumn{2}{|l|}{ Marital status } \\
\hline Single & 30.3 \\
\hline Married & 69.7 \\
\hline \multicolumn{2}{|l|}{ Residential location } \\
\hline Urban & 61.1 \\
\hline Rural & 38.9 \\
\hline \multicolumn{2}{|l|}{ Monthly salary } \\
\hline$\leq \mathrm{RM} 2,500$ & 9.5 \\
\hline RM2,501-RM5,000 & 36.5 \\
\hline RM5,001-RM7,500 & 15.2 \\
\hline RM7,501-RM10,000 & 23.2 \\
\hline$>\mathrm{RM} 10,000$ & 15.6 \\
\hline
\end{tabular}

\section{Determining the Level of Concern for the Environment}

The 5-point Likert scale of (5) Strongly agree to (1) Strongly disagree was used to assess respondents' concerns about the environment during the Covid-19 pandemic. Meanwhile, the level of concern was determined by calculating the total mean of the measurement construct and divided by the number of items of concern for the environment to produce the overall mean. Overall, the study found that respondents' concern for the environment during the Covid-19 pandemic was high $[\mathrm{M}=4.055, \mathrm{SD}=.3828]$. Table 2 shows the determinant of respondents' level of concern for the environment during the Covid-19 pandemic based on the mean findings of the measurement construct. 
INTERNATIONAL JOURNAL OF ACADEMIC RESEARCH IN BUSINESS AND SOCIAL SCIENCES

Vol. 10, No. 15, Youth and Community Wellbeing: Issues, Challenges and Opportunities for Empowerment V1. 2020, E-ISSN: 2222-6990 @ 2020 HRMARS

Table 2: Respondents' Level of Concern towards the Environment $(n=211)$

\begin{tabular}{ccccc}
\hline Level & No & Percentage & Mean & SD \\
\hline & & & 4.055 & .3828 \\
Moderate $(2.44-3.66)$ & 24 & 11.4 & & \\
High(3.67- 5.00) & 187 & 88.6 & & \\
\hline
\end{tabular}

Table 3 shows the descriptive distribution of each item of environmental concern during the Covid-19 pandemic. The study indicates that of the 26 measurement items, only 6 items were given a moderate score [ $\mathrm{M}=2.44-3.66]$ by the respondents. The items are 'I practice separation of garbage/waste at home before disposing it' [M = 3.58, SD = .975]; 'I grow my own basic food items such as vegetables and herbs (lemongrass, turmeric, curry leaves, pandan leaves) around my house' $[\mathrm{M}=3.56, \mathrm{SD}=1.104]$; 'I collect used cooking oil for processing for other uses' $[\mathrm{M}=3.43 ; \mathrm{SD}=1,059]$; 'I often order food through Food Panda or Grab Food in just the right quantity' [M=3.42; SD =1.208]; 'I collect rainwater for uses such as watering plants and washing vehicles' [M=3.22; $S D=1.131]$; and 'I turn leftover food into compost for use as plant fertiliser' [M = 3.17; SD = .993].

Meanwhile, the three main items that were given a high score [ $M=3.67-5.00]$ by the respondents are 'Environment is important to me because it provides essentials such as oxygen and water' [M = 4.82; SD = .497]; 'Environment is important to me because it offers aesthetic value like beautiful scenery' [M = 4.74; $S D=.481]$; and 'Environment is important to me because it offers elements for self and mind therapy such as fishing and picnicking' [M=4.66; SD $=.531]$.

Table 3: Mean Distribution and Standard Deviation of Respondents' Concern for the Environment during the Covid-19 Pandemic $(n=211)$

\begin{tabular}{|c|c|c|c|}
\hline No. & Concern for the Environment Item & Mean & SD \\
\hline 1. & $\begin{array}{l}\text { The environment is important for me as it is a source of oxygen and air for } \\
\text { humans. }\end{array}$ & 4.82 & .497 \\
\hline 2. & The environment is important for me as it a source of food. & 4.64 & .547 \\
\hline 3. & The environment is important for me as it is a source of natural medicine. & 4.46 & 611 \\
\hline 4. & $\begin{array}{l}\text { The environment is important for me as it offers aesthetic values such as } \\
\text { beautiful sceneries. }\end{array}$ & 4.74 & .481 \\
\hline 5. & $\begin{array}{l}\text { The environment is important for me as it offers elements for self and mind } \\
\text { therapy such as fishing and picnicking. }\end{array}$ & 4.66 & .531 \\
\hline 6. & $\begin{array}{l}\text { I get the latest information about the environment from print media such } \\
\text { as the newspaper. }\end{array}$ & 3.90 & .752 \\
\hline 7. & $\begin{array}{l}\text { I get the latest information about the environment from social media such } \\
\text { as Facebook, Twitter etc. }\end{array}$ & 4.41 & .629 \\
\hline 8. & Environmental pollution is of great concern to me. & 4.60 & .726 \\
\hline 9. & My behaviour affects the environment. & 4.21 & .826 \\
\hline 10. & I do not waste electricity. & 4.17 & .647 \\
\hline 11. & I do not waste water. & 4.16 & .649 \\
\hline 12. & I collect rainwater to water plants and wash the car. & 3.22 & 1.131 \\
\hline
\end{tabular}


13. I grow my own basic food items such as vegetables and herbs (lemongrass, $\quad 3.56 \quad 1.104$ turmeric, curry leaves, pandan leaves) around my house.

14. I cook just enough food for the family to avoid wastage.

$4.24 \quad .648$

15. I often order food via Food Panda or Grab in the right quantity.

$3.42 \quad 1.208$

16. I separate garbage/waste at home before disposing them.

$3.58 \quad .975$

17. I always practice recycling.

$3.67 \quad .892$

18. I always reuse things which are still useable.

$4.02 \quad .677$

19. I turn food waste into compost to be used as plant fertiliser.

$3.17 \quad .993$

20. I collect used cooking oil to be processed for other uses.

$3.43 \quad 1.059$

21. I support the sale of environmentally friendly products.

$4.33 \quad .666$

22. I am willing to spend more on environmentally friendly products.

$3.82 \quad .768$

23. I buy basic necessities that is food in large quantities to avoid frequent use of the vehicle.

24. I always bring my own plastic bag when shopping for basic necessities such as food.

25. I do not dispose items like face masks and rubber gloves just about everywhere.

26. I will report to the authorities if I witness any act of polluting the environment.

T-independent tests were also used to see if there was a difference in the level of concern for the environment during the Covid-19 pandemic among respondents based on selected demographic profiles namely location of residence and marital status. The analysis found that there was no significant difference in the level of respondents' concern for the environment during the Covid-19 pandemic either among those living in the urban areas [M $=4.0839 ; \mathrm{SD}=.35949$ ] or in rural areas $[M=4.0096 ; S D=.41514 ; t(1,378) ; p=.170]$. The analysis also found that there was no significant difference in the level of respondents' concern for the environment during the Covid-19 pandemic either among those who were single $[M=3.9771 ; S D=.37266]$ or married $[M=4.0890 ; S D$ $=.38348 ; t(-1,966) ; p=.051]$. Table 4 summarises the differences in respondents' level of concern for the environment during the Covid-19 pandemic based on the selected demographic profiles.

Table 4: Differences in Respondents' Levels of Concern for the Environment during Covid 19 Compilation based on Selected Demographic Profiles $(n=211)$

\begin{tabular}{clllll}
\hline Profile & $\mathbf{n}$ & Mean & SD & $\boldsymbol{t}$ & $\boldsymbol{p}$ \\
\hline Location & & & & 1.378 & .170 \\
$\quad$ Urban Areas & 129 & 4.0839 & .35949 & & \\
$\quad$ Rural Areas & 82 & 4.0096 & 41514 & & \\
$\begin{array}{c}\text { Maritial Status } \\
\text { Single }\end{array}$ & 64 & 3.9771 & .37266 & -1.966 & .051 \\
$\quad$ Married & 147 & 4.0890 & .38348 & & \\
\hline
\end{tabular}

This study shows a positive development among parts of the Malaysian society. It is commonly acknowledged that Selangor is the fastest growing state in Malaysia. For almost 10 years, Selangor is still seen as the biggest contributor to Malaysia's GDP, which is over $20 \%$. The percentage 
INTERNATIONAL JOURNAL OF ACADEMIC RESEARCH IN BUSINESS AND SOCIAL SCIENCES

Vol. 10, No. 15, Youth and Community Wellbeing: Issues, Challenges and Opportunities for Empowerment V1. 2020, E-ISSN: 2222-6990 @) 2020 HRMARS

of Selangor State GDP contribution to Malaysia's GDP in 2017 increased to $23 \%$ from $22.7 \%$ the previous year. Meanwhile, the growth rate of Selangor GDP in 2017 was $7.1 \%$ compared to $4.8 \%$ in 2016 (Selangor Government, 2019).

The rapid economic growth of the state through various industrial sectors is a major concern among various parties in the society who are deeply apprehensive about its negative impact on the environment. For example, a study conducted by Samion et. al., (2016) on the quality of life of the physical surroundings and environment of suburban communities in Hulu Langat, Selangor found that respondents viewed the status of their physical surroundings and environment was on a scale of 3 with a percentage of 46.8 percent, which is at a moderate level. The status of being very satisfied with their physical surroundings and environment reached 2.6 percent while the level of dissatisfaction and very dissatisfied reached 4.4 percent. The quality of life status for the physical surroundings and the environment recorded a percentage of more than 50 percent for the subindicators of 'electricity' and 'water supply is always adequate'. Meanwhile, the 'river water' and 'drainage cleanliness' sub-indicators recorded the highest dissatisfaction of 24.1 percent. Besides that, sub-indicators of 'noise', 'environmental conditions', 'garbage disposal system' and 'air hygiene' recorded the dissatisfaction level of more than 10 percent. The overall physical surroundings and environment score, which was assessed from a minimum score of 12 to a score of 60 for the population of Hulu Langat district, reached $40.61 \pm 6.05$. The measurement instruments of the study of Samion et. al., (2016) included Physical Surroundings and Environment indicators, which contained 12 sub-indicators to determine the quality of life in the rural communities. The Physical Surroundings and Environmental aspects analyzed were garbage disposal system, natural resource conditions: forest/green area/park, fixed forest policy/green area/park, river/drainage water hygiene, environmental conditions, erosion/landslide/soil sediment/flash floods, drinking water, odour, noise, electricity supply, water supply and air quality.

The findings of the current study clearly show a high level of concern for the environment among the community in Selangor even during the period of MCO due to the Covid-19 pandemic. This situation does not completely change the findings of the previous studies (Othman \& Umar, 2000; Sabri \& Yong, 2006; Samion et. al., 2016) despite the community being affected by various other physical and social pressures as a result of the MCO. Nonetheless, the current study clearly shows that the practices of green consumption among the community in Selangor is still at a moderate level. The current findings also support the findings of a study by Sabri and Yong (2006), who found that more than $70 \%$ of the respondents observed had a high level of concern for the environment, but had a moderate level of green consumption practices.

Finally, there is no difference in terms of the level of concern among the community in Selangor towards the environment across residential locations as shown in the current study. In other words, both the urban and rural communities in the state have a high level of concern for environmental issues even during the Covid-19 pandemic. This shows the various efforts to preserve the environment that have been done thus far are effective in increasing the level of public concern on environmental issues. This finding again supports the findings of the previous studies (Othman \& 
INTERNATIONAL JOURNAL OF ACADEMIC RESEARCH IN BUSINESS AND SOCIAL SCIENCES

Vol. 10, No. 15, Youth and Community Wellbeing: Issues, Challenges and Opportunities for Empowerment V1. 2020, E-ISSN: 2222-6990 @) 2020 HRMARS

Umar, 2000; Sabri \& Yong, 2006) involving urban population, and a study by Samion et. al. (2016) involving urban and rural population.

\section{Conclusion}

Although there is some truth to the general view that the enforcement of MCO due to the Covid-19 pandemic is a contributor to the aspect of environmental sustainability in Malaysia, there is a possibility that the current high level of concern in society towards the environment is also a contributor. The current study shows a very positive sign among parts of the Malaysian society towards realising efforts to continuously preserve the environment by various parties in Malaysia. Although the findings of the current study show that the practices of green consumption among the community is still seen at a moderate level, the study can not ascertain whether the enforcement of MCO contributes to this level of practice. This is because the design of the study does not examine the pre and post study practices. However, what can be said is that the findings of the current study contain similarities with the findings of previous studies in the context of green practices in society. Nevertheless, this element needs to be given special attention as the practice of green consumption is indeed an important behavior that is crucial to be instilled in society towards realising the efforts to maintain environmental sustainability. The state of merely being concern but lack of action is feared to fail in changing the situation for the better. Academic studies to measure the level of green consumption practices in society need to be done from time to time so that appropriate efforts by certain parties can be mobilized more efficiently. The study at the same time also calls for more aggressive and effective efforts from the Institutions of Higher Learning (HLI) with expertise in this field to approach the community through various educational and extension programs related to the environment, especially in terms of effective green consumption practices.

\section{References}

Ahmad, J. H., Mustafa, H., Abd Hamid, H., \& Wahab, J. A. (2011). Pengetahuan, sikap dan amalan masyarakat Malaysia terhadap isu alam sekitar (knowledge, attitude and practices of malaysian society regarding environmental issues). Akademika, 81(3).

Ashaario. (2009). Kajian kesedaran alam sekitar. Online access: http://ashaarioashaario.blogspot.com/2009/12/bab-i-pendahuluan-nilai-murni-terhadap.html. Retreived 15 Mei 2010.

Fourth Edition Hall Dictionary. (2017). Dewan Bahasa dan Pustaka: Kuala Lumpur.

Idrus, S. (2015). Kesedaran alam sekitar rakyat kita masih rendah. Berita Harian. 5 Jun 2015.

Malaysia Environmental Department. (1997). Environmental Quality Report 1997. Kuala Lumpur: Jabatan Alam Sekitar.

Meenakshi Raman. (2020). Pengajaran Covid-19: Hindari malapetaka alam masa depan. Online access: https://www.malaysiakini.com/letters/522062

Mutalib, Z. A. (2019). Sikap masyarakat tak seiring status maju negara. Berita Harian. 29 Julai 2019.

Othman, M. N., \& Umar, S. M. (2000). Kesedaran Terhadap Alam Sekitar: Kajian Perbandingan Antara Pengguna Melayu dan Cina Bandar. Malaysian Journal of Consumer and Family Economics, 3, 42-50.

Said, A. M., Paim, L. H., \& Masud, J. (2003). Environmental concerns, knowledge and practices gap among Malaysian teachers. International Journal of Sustainability in higher education. 
Samion, S. S., Awang, A., \& Noviart, N. (2016). Kualiti hidup persekitaran fizikal dan alam sekitar masyarakat pinggir bandar di daerah Hulu Langat, Selangor. Seminar Proceeding of Serantau Pengurusan Persekitaran 2016.

Samsudin, N. A., \& Iksan, Z. H. (2015). Kesedaran alam sekitar melalui aplikasi kendiri alam sekitar (KAKAS). Environmental Awareness Through Self Application Environment, 18(2), 23-31.

Selangor Government. (2019). Selangor State Budget Presentation Text 2019. Online access: https://www.selangor.gov.my/index.php/pages/view/3055

Starke, L. (1990). Signs of Hope: Working Towards Our Common Future. New York: Oxford University Press.

Wahid, N. A., Rahbar, E., \& Shyan, T. S. (2011). Factors influencing the green purchase behavior of Penang environmental volunteers. International Business Management, 5(1), 38-49.

Zurina, M., \& Norjan, Y. (2003). Kesedaran alam sekitar: tinjauan awal di kalangan pelajar universiti Kebangsaan Malaysia. In Prosiding Seminar Kebangsaan Pengurusan Persekitaran (pp. 8-9). 